\title{
Development of NiCrSiBC Weld Hardfacing Approach for P91 Steels Used in Steam Turbine Components
}

\author{
H. V. Naik ${ }^{1 *}$ (D) V. D. Kalyankar ${ }^{1}$ (D) \\ ${ }^{1}$ Sardar Vallabhbhai National Institute of Technology, Surat, Gujarat, India.
}

Como citar: Naik HV, Kalyankar VD. Development of NiCrSiBC Weld Hardfacing Approach for P91 Steels Used in Steam Turbine Components. Soldagem \& Inspeção. 2021;26:e2608. https://doi.org/10.1590/0104-9224/SI26.08

\begin{abstract}
P91 steels are used as substrate material for steam turbine components like bush, valve seat internals, and engineering valves. These components have hardfacing of cobalt-based material to reduce the high temperature wear loss and to improve the surface hardness. However, delamination failure and higher heat affected zone (HAZ) hardness were identified challenges for P91 steels. Hence, this demands the development of a suitable weld hardfacing approach to resolve the said challenges. In this work, $\mathrm{NiCrSiBC}$ (Colmonoy 6) has been considered as a hardfacing material to replace cobalt-based Stellite 6 material due to elimination of radiation activity, lower cost, and higher coating hardness. FCAW and PTA techniques were used to deposit buffer layer (SS-309L) and hardfacing layer (NiCrSiBC) respectively. Sample WBL (with deposition of buffer layer) and sample WOBL (without deposition of buffer layer) are considered approaches to study the metallurgical characterization for each case. Higher coating hardness, lower HAZ hardness and lower Fe dilution were observed in sample WBL. $\mathrm{Cr}_{7} \mathrm{C}_{3}, \mathrm{Cr}_{2} \mathrm{~B}$, and $\mathrm{Cr}_{5} \mathrm{~B}_{3}$ hard phases in block shape together with $\gamma$ - nickel matrix solid solution was observed in coating region of sample WBL. Overall, sample WBL approach was considered to overcome weld hardfacing challenges for steam turbine industries.
\end{abstract}

Key-words: Weld hardfacing; Buffer layer; P91 steel; NiCrSiBC hardfacing; Metallurgical characterization

\section{Desenvolvimento da abordagem de revestimento duro de solda $\mathrm{NiCrSiBC}$ para aços P91 usados em componentes de turbinas a vapor}

\begin{abstract}
Resumo: Os aços P91 são usados como substrato para componentes de turbinas a vapor, como buchas, componentes internos de assento de válvula e válvulas de engenharia. Esses componentes possuem revestimento duro de material à base de cobalto para reduzir a perda por desgaste em alta temperatura e melhorar a dureza da superfície. No entanto, falha de delaminação e maior dureza da zona afetada pelo calor (ZAC) foram desafios identificados para os aços P91. Portanto, isso exige a necessidade de desenvolver uma abordagem de revestimento de solda adequado para resolver os referidos desafios. Neste trabalho, $\mathrm{NiCrSiBC}$ (Colmonoy 6) foi considerado como um material de revestimento para substituir o material Stellite 6 à base de cobalto devido à eliminação da atividade de radiação, menor custo e maior dureza do revestimento. As técnicas FCAW e PTA foram usadas para depositar a camada de buffer (SS-309L) e a camada de revestimento duro ( $\mathrm{NiCrSiBC}$ ), respectivamente. No presente estudo, foi realizada a caracterização metalúrgica das condições WBL (com camada de amanteigamento) e WOBL (sem a camada de amanteigamento). Maior dureza de revestimento, menor dureza $\mathrm{HAZ}$ e menor diluição de Fe foram observadas na amostra WBL. Fases duras $\mathrm{Cr}_{7} \mathrm{C}_{3}, \mathrm{Cr}_{2} \mathrm{~B}$ e $\mathrm{Cr}_{5} \mathrm{~B}_{3}$ em forma de bloco juntamente com solução sólida de matriz de níquel $\curlyvee$ foram observadas na região de revestimento da amostra WBL. No geral, a abordagem WBL da amostra foi considerada como benéfica para superar os desafios de revestimento de solda para as indústrias de turbinas a vapor.
\end{abstract}

Palavras-chave: Revestimento de solda; Camada de buffer; Aço P91; Revestimento NiCrSiBC; Caracterização metalúrgica

\section{Introduction}

P91, P92 grades of steel are used recently in ultra-super and super critical thermal power plants for piping, engineering valves, disks and thermal shield components' material [1-4]. P91 steels are commonly used as the substrate material for boiler and turbine components owing to enhanced creep resistance and compatible weldability. Some of the components such as engineering steam valves, bushes, steam inlet valves, etc. are operated at elevated temperature $\left(\sim 550-610^{\circ} \mathrm{C}\right)$ and high pressure $\left(\sim 270 \mathrm{~kg} / \mathrm{cm}^{2}\right)$ service conditions [3,4]. However, engineering valves and steam inlet valves are exposed to occasional metal to metal contact during opening and closing of valves in different service conditions. Few of them such as valve discs and seats, would furthermore need good hardness to improve wear resistance [4]. Hence, bushes and valve seat components demand 
higher surface hardness to improve high temperature wear resistance against opening and closing of valves and disks [3,4]. In order to increase wear resistance and hardness, weld deposition of cobalt based and nickel based hardfacing materials are practiced in steam turbine industries $[3,4]$. But it poses the recurrent problem of delamination failures between P91 steels and hardfacing material due to detrimental stress concentrations, martensite formation in HAZ and harmful carbide phases like $\mathrm{M}_{23} \mathrm{C}_{6}$ phases and sigma $(\sigma)$ phase during artificial or natural aging [2-4]. In addition to $\sigma$ phase and $\mathrm{M}_{23} \mathrm{C}_{6}$ phases, chromium ( $\mathrm{Cr}$ ) rich carbide phase at the fusion line exhibits the higher hardness at the interface between P91 and hardfacing layer. It can be considered as the sole cause of increased HAZ hardness and delamination failure of weld hardfacing layer [4]. To overcome this challenge, the researchers have recommended to deposit buffer layer in between P91 and hardfacing material with an aim to reduce hardness at the interface or HAZ [2-4]. Such a practice leads to a functionally graded material in which the buffer layer has an intermediate thermal expansion behavior to that of the hardfacing and substrate.

In the recent past, AWS A5.21 ERCCoCr-E [4], austenitic stainless steel (SS-309) [3], AWS A5.14 ERNiCrMo-3 [2] and AWS A5.14 ERNiCr-3 [5] have been investigated as some buffer layer materials to overcome delamination challenge for bush and valve seat components. In addition to this challenge, researchers have claimed the need to replace cobalt based Stellite 6 hardfacing materials with the P91 substrate materials [3]. Cobalt based materials are often observed as causing radiation activity, $B C C$ microstructure in HAZ and the formation of $\sigma$ phase in given application $[2,4,6]$. Hence, nickel based hardfacing materials such as A 5.21 ERNiCr-B, A 5.21 ERNiCr-C, NiCrBSi, etc. have been suggested and investigated after the weld deposition of buffer layer material $[2,7]$. However, hardness of hardfacing layer has been compromised with suggested solutions in terms of buffer layer [5] and nickel based hardfacing layer [2,7] for the said challenges. Hardness can be critical investigation aspect where industrial applications demand high temperature wear resistance and increased life span of manufacturing components [5,8]. Hence, the influence of suitable buffer layer, higher coating hardness, lower HAZ hardness and replacement of cobalt based hardfacing materials are targeted research areas in this work. In the present research work, SS-309L material has been considered as buffer layer material due to lower HAZ hardness and lower dilution of Fe in hardfacing layer compared to other investigated materials like AWS A5.14 ERNiCrMo-3, AWS A5.21 ERCCoCr-E [3-5]. FCAW process has been considered for depositing buffer layer as per the recommendations of the researchers and industry as a standard method for buffer layer applications due to lower heat input and higher productivity $[2,3,7]$. Further, NiCrSiBC (Colmonoy-6) has been considered as a hardfacing material to replace cobalt based Stellite 6 material. Elimination of radiation activity, lower cost, higher coating hardness, tendency to form oxide layer at high temperature conditions and lower solubility of carbon in nickel are main reasons behind this selection [2,7,9-11]. In addition to this, an important reason for choosing nickel-based alloys is the ability to maintain a uniform chemical composition during different cooling conditions [11]. Hemmati et al. [12] have studied the impact of different cooling rates on chemical composition of nickel-based alloy through different thermal analysis experiments. Higher cooling rates hamper the formation of $\mathrm{Cr}_{5} \mathrm{~B}_{3}$ borides which is due to the peritectic reaction $\left(\mathrm{L}+\mathrm{CrB} \rightarrow \mathrm{Cr}_{5} \mathrm{~B}_{3}\right)$ that takes place at $1900{ }^{\circ} \mathrm{C}$ in the $\mathrm{Cr}-\mathrm{B}$ binary phase diagram. The nucleation of the boride $\mathrm{Cr}_{5} \mathrm{~B}_{3}$ on $\mathrm{CrB}$ phase is driven by the elemental diffusion of $\mathrm{B}$ and $\mathrm{Cr}$ elements [12]. Hence, it allows to associate a high solidification rate and uniform chemical composition with conquest of the $\mathrm{Cr}_{5} \mathrm{~B}_{3}$ precipitation. It is relevant to extrapolate these findings for considered coatings, buffer layer and hardfacing methods. As the heat transferred between coating and substrate is imposed by coating technique, so the microstructure of materials affects the final outcomes $[12,13]$. PTA technique has been considered for deposition of NiCrSiBC hardfacing material due to minimal dilution of Fe and higher deposition rates [2-5].

In the present work, two approaches have been selected to ensure an effective weld hardfacing layer with higher coating hardness, lower HAZ hardness and desired microstructural characteristics with reduced chances of cracks during service life. The first approach deals with direct deposition of $\mathrm{NiCrSiBC}$ hardfacing material and the second approach deals with the deposition of NiCrSiBC hardfacing material on SS-309L buffer layer material. In both the approaches, P91 steel has been considered as the substrate material and $\mathrm{NiCrSiBC}$ as the hardfacing material for fair comparison purpose. Further, FCAW and PTA techniques were used to deposit buffer layer (SS-309L) and hardfacing layer ( $\mathrm{NiCrSiBC}$ ) respectively for the investigations. The main objective of both the approaches was to investigate an influence of buffer layer on HAZ hardness, coating microstructure and coating hardness.

\section{Experimental Details}

\subsection{Materials}

Initially, P91 steel test plates as the substrate material have been prepared with the dimensions of $200 \mathrm{~mm} \times 100 \mathrm{~mm} x$ $14 \mathrm{~mm}$ with the help of water jet cutting. SS-309L filler as buffer layer material and NiCrSiBC as hardfacing material are dried in muffle furnace at $100^{\circ} \mathrm{C}$ for 1 hour. The diameter of buffer layer FCAW material (SS-309L) and hardfacing PTA powder (NiCrSiBC) is $1.2 \mathrm{~mm}$ and $60-180 \mu \mathrm{m}$ respectively. Table 1 represents the chemical composition provided by the suppliers of the substrate, buffer layer and hardfacing material. 
Table 1. Chemical composition of considered materials.

\begin{tabular}{|c|c|c|c|c|c|c|c|c|c|}
\hline Description & Element (Wt. \%) & C & $\mathrm{Cr}$ & $\mathrm{Mn}$ & Si & $\mathrm{Ni}$ & Mo & v & $\mathrm{Fe}$ \\
\hline \multirow[t]{2}{*}{ Substrate } & P91 steel & 0.08 & 8.56 & 0.39 & 0.3 & 0.25 & 0.9 & 0.153 & Bal. \\
\hline & & C & $\mathrm{Cr}$ & $M n$ & Si & $\mathrm{Ni}$ & $\mathbf{P}$ & $S$ & $\mathrm{Fe}$ \\
\hline \multirow[t]{2}{*}{ Buffer layer } & SS-309L & 0.03 & 23 & 1.2 & 0.5 & 12.6 & 0.017 & 0.008 & Bal. \\
\hline & & C & $\mathrm{Cr}$ & B & Si & Co & $\mathrm{Fe}$ & \multicolumn{2}{|c|}{$\mathrm{Ni}$} \\
\hline Hardfacing & $\mathrm{NiCrSiBC}$ & 0.6 & 16.64 & 3.02 & 4.52 & 0.04 & 4.54 & \multicolumn{2}{|c|}{ Balanced } \\
\hline
\end{tabular}

\subsection{Weld deposition approaches}

In this work, the processing conditions and parameters have been assessed and chosen based on the literature in accordance with preliminary trial runs and industrial guidelines, with the aim of depositing crack-free beads with an improved surface finish $[2,3]$. In this work, NiCrSiBC hardfacing has been deposited using PTA technique over P91 steel with buffer layer (indirect deposition) of SS-309L (1.2 mm diameter) using FCAW method. FCAW process parameters such as current (250-270 A), voltage $(26-28 \mathrm{~V})$, feed rate $(8 \mathrm{~mm} / \mathrm{min})$, flow rate $(20 \mathrm{l} / \mathrm{min})$, shielding gas composition (Argon $80 \%+\mathrm{CO}_{2} 20 \%$ ), travel speed (360 $\mathrm{mm} / \mathrm{min}$ ) have been chosen in optimized conditions to deposit buffer layer (SS-309L) based on trial experiments and literature support [2]. It is followed by $\mathrm{NiCrSiBC}$ hardfacing which was deposited using PTA technique over P91 steel without buffer layer (direct deposition). Indirect deposition (with buffer layer) and direct (without buffer layer) deposition were addressed as sample WBL and sample WOBL respectively. Graphical representation of sample WBL and sample WOBL approaches are depicted in Figure 1 and Figure 2.

Sample WBL

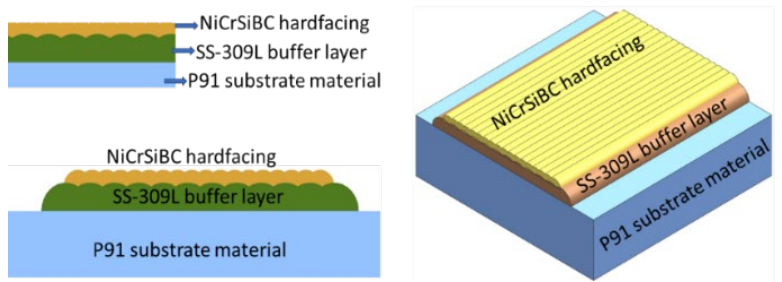

Figure 1. Indirect deposition with buffer layer (sample WBL).

Sample WOBL

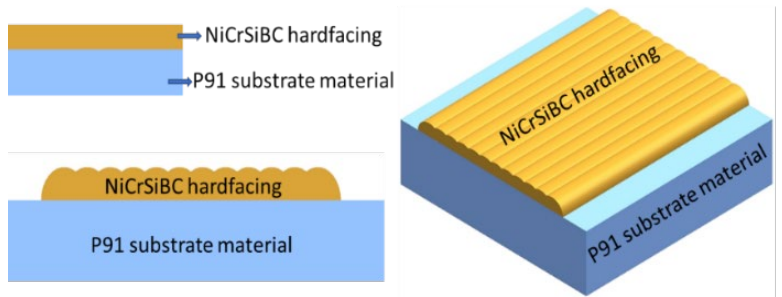

Figure 2. Direct deposition without buffer layer (sample WOBL).

These two weld deposition approaches are then investigated based on metallurgical characterization and microhardness measurements. After the elimination of possible crack formation during weld deposition over P91 steel, process parameters are optimized for both approaches i.e. sample WBL (with buffer layer) and sample WOBL (without buffer layer) and the same are shown in Table 2.

There are differences in some of the parameters used for each hardfacing operation. This resulted from the need to consider the presence of the intermediate SS-309L layer in sample WBL. This caused, for instance, a difference of 6\% in heat input. However, the authors consider that this and other differences were not relevant for the results of the present work because they should have had little influence, for instance, in the characteristics of the P91 HAZ due to the presence of the intermediate layer in sample WBL. Since, the aim was to develop suitable hardfacing approach with crack free deposition, parameters are optimized based on appropriate material combination and processing conditions. It is essential to select preheat and interpass conditions in order to produce crack free deposition. If it is selected the same, the cracks have been observed due to generation of residual thermal stresses.

Direct deposition of NiCrSiBC material i.e., without buffer layer has been conducted using PTA technique. After weld deposition, stress relieving post weld heat treatment (PWHT) was applied in order to relieve the stresses [2,3], since these 
samples will be subjected to machining. All samples were subjected to PWHT at $750{ }^{\circ} \mathrm{C}$ temperature for soaking period of 60 minutes. Further, indirect deposition of NiCrSiBC material i.e. with buffer layer (SS-309L) has been conducted using PTA technique. Buffer layer of SS-309L material has been deposited on P91 steel using FCAW process. After deposition of buffer layer, PWHT cycle has been carried out at $750{ }^{\circ} \mathrm{C}$ temperature for soaking period of 60 minutes. After the weld deposition of buffer layer, samples are cooled down at $110^{\circ} \mathrm{C}$ and then the same are once again heated upto $400{ }^{\circ} \mathrm{C}$ and kept for 1 hour to remove an excess hydrogen to prevent hydrogen induced cracking as per dehydrogenation heat treatment (DHT). This treatment helps to reduce the chances of hydrogen-induced cracking after the solidification of welded material. Immediate PWHT after buffer layer and DHT are unique practices adopted in accordance with industrial practice in order to relieve stresses before hardfacing, the removal of excess hydrogen and lowering the HAZ hardness [2,3]. Thus, sample WBL and sample WOBL have been prepared in accordance with mentioned parameters in Table 2 with an ensured defect free surface for further investigations like mechanical and metallurgical characterizations.

Table 2. Optimized processing conditions and parameters.

\begin{tabular}{|c|c|c|}
\hline & Sample WBL & Sample WOBL \\
\hline Processing conditions & $\begin{array}{l}\text { With SS-309L buffer layer (Indirect } \\
\text { deposition) }\end{array}$ & Without buffer layer (Direct deposition) \\
\hline Chosen parameters & Range & Range \\
\hline Current $(A)$ & $155-160$ & $160-165$ \\
\hline Travel speed (mm/min) & 90 & 78 \\
\hline Powder feed rate (g/min) & 27.3 & 27.3 \\
\hline Plasma gas flow rate (lpm) & 3.5 & 3.5 \\
\hline Carrier gas flow rate (Ipm) & 1.5 & 1.5 \\
\hline Shielding gas flow rate (lpm) & 12 & 12 \\
\hline Oscillation speed (mm/min) & 560 & 498 \\
\hline Standoff distance (mm) & $11-13$ & $10-12$ \\
\hline Preheating temperature $\left({ }^{\circ} \mathrm{C}\right)$ & $275-300$ & $150-180$ \\
\hline Interpass temperature $\left({ }^{\circ} \mathrm{C}\right)$ & $400-450$ & $250-300$ \\
\hline
\end{tabular}

\subsection{Characterization techniques}

\subsubsection{Mechanical and dimensional characterization}

After deposition in both approaches, the samples were subjected to mechanical and dimensional characterizations including the coating thickness and hardness through corresponding methods according to standard and industrial practice. As per ASME section-IX QW 453, these samples were subjected to macro-examination, chemical analysis and dye penetration (DP) test for ensuring soundness and metallurgical bonding of weld overlay [14]. All samples for mechanical characterizations were prepared according to corresponding testing method and required dimension and these samples were prepared using electrical discharge machining (EDM) by cutting perpendicular to weld direction in required dimension. Weld deposition characteristics were observed in terms of crack free deposition, uniform deposition thickness and metallurgical bonding through macro examination. Chemical composition was checked using positive material identification (PMI) before and after hardfacing. Coating thickness was measured using optical micrographs by examining 4 spots in both samples. Vickers microhardness testing machine was considered to measure microhardness for without and with buffer layer approaches individually. Test parameters were taken at testing load of 1000 gf having dwell time of 10 seconds for all indentations [2]. There were 20 indentations taken to get an accurate hardness profile across all the regions at uniform distance of $0.5 \mathrm{~mm}$.

\subsubsection{Microstructural characterization}

Samples were etched and prepared in accordance with ASTM E407 [15] for metallographic studies like elemental dilution, microstructural changes, HAZ width and phase analysis. All samples for microstructural characterizations were machined using EDM to required dimensions and these samples were mounted using cold mounting technique to each microscopic tool after etching. Further, samples were etched chemically with Viella's reagent ( $5 \mathrm{cc} \mathrm{HCL}+2$ gms Picric acid $+100 \mathrm{cc}$ Ethyl alcohol) and $\mathrm{HNO}_{3}+\mathrm{HCL}(1: 4)$ for both approaches. The dilution was observed for the Fe element in the hardfacing, based on the results of energy dispersive spectroscopy (EDS), with the chemical composition of the hardfacing powder as reference. This analysis technique is used to check dilution of element ( $\mathrm{Fe}$ ) and elemental composition in these regions. Equation 1 was utilized for the 
calculations for Fe dilution, where; $Y_{h}$ is the percentage by weight of Fe in the hardfacing; $Y_{s}$ is the percentage of Fe in the substrate; and $Y_{p}$ is the percentage of Fe in the hardfacing powder material $[10,13]$.

Dilution $(\%)=\frac{Y h-Y p}{Y s-Y p}$

Different microstructural zones of interest like hardfacing layer, interface and HAZ region for both approaches were observed with an optical microscope coupled with an image analyzing software. Further, scanning electron microscope (SEM) was used to analyze microstructural changes present in with and without buffer layer approaches. SEM is a significant research tool due to its ability to generate different contrast based on specific atomic number which helps to identify borides and carbides. These phases present in hardfacing were identified by X-ray diffraction (XRD) machine having X-ray wavelength of $\mathrm{K}_{\alpha}=1.5406 \AA$ used at operating settings of $45 \mathrm{kV}$ and $40 \mathrm{~mA}$ for the analysis of phases present in the samples. EDS line scan analysis and point analysis were carried out with low acceleration electron $(5 \mathrm{kV})$ for both approaches.

\section{Results and Discussion}

\subsection{Weld deposition characteristics}

Macro-examinations (magnification:15X) have confirmed defect-free metallurgical bonding without any cracks at the interface as shown in Figure 3.

(Sample WBL)

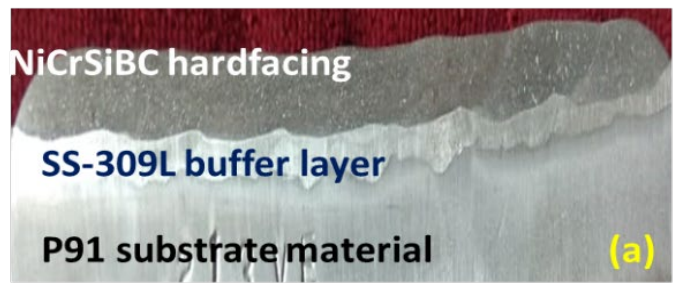

(Sample WOBL)

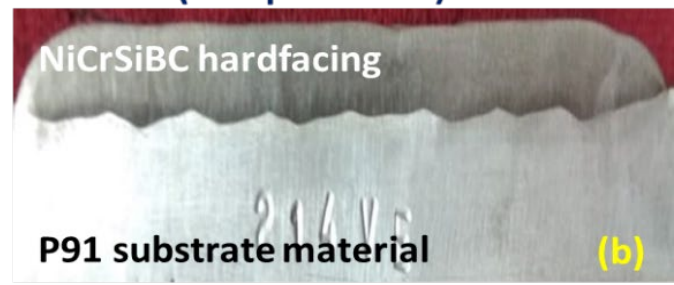

Figure 3. Macro examinations results for (a) Sample WBL (b) Sample WOBL.

The results obtained from PMI showed similar chemical composition as hardfacing layer material after deposition that ensures good process and material compatibility. Both samples are subjected to DP test and visual inspection which show clear deposited surface. Further, optical micrographs are represented in Figure 4 obtained at magnification of 20X which represents the coating thickness of both approaches.

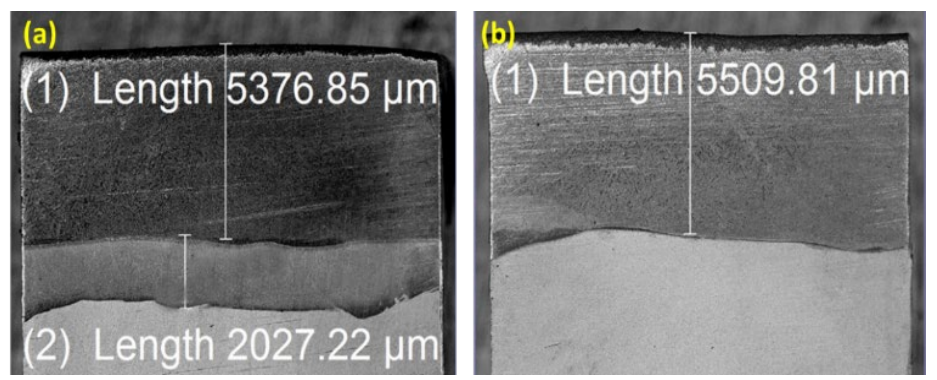

Figure 4. Example of coating thickness (a) Sample WBL (b) Sample WOBL.

Figure 4 shows no sign of cracks, defects or porosity in hardfacing layer, buffer layer and substrate material which proves the compatibility of material and process with P91 steels. Uniform coating thickness of $5.5 \mathrm{~mm}$ is observed in hardfacing layer deposited by PTA process for both samples. Preheat temperature and interpass temperature conditions were major changes in parameters' setting which are due to varied thermal coefficient of expansion of two materials (SS-309L and P91 steel). Thermal coefficient of expansion affects the accommodation of residual thermal stresses during and after weld deposition of materials. In sample WOBL, PTA hardfacing is performed directly on P91 steel whereas, in sample WBL, it is performed on SS-309L steel intermediate layer. Sample WBL required more preheat and interpass temperature conditions due to higher thermal coefficient of expansion $\left(14.9 \mathrm{\mu m} / \mathrm{m}^{\circ} \mathrm{C}\right)$ than sample WOBL $\left(12.4 \mu \mathrm{m} / \mathrm{m}^{\circ} \mathrm{C}\right)$. Both materials are having difference of $15 \%$ in thermal 
coefficient of expansion. Hence, it is important to consider the same while deciding preheat and interpass conditions to avoid any possible residual cracks.

\subsection{Microhardness study}

Figure 5 shows the comparison between various zones categorized in three regions namely coating, interface and substrate for two approaches.

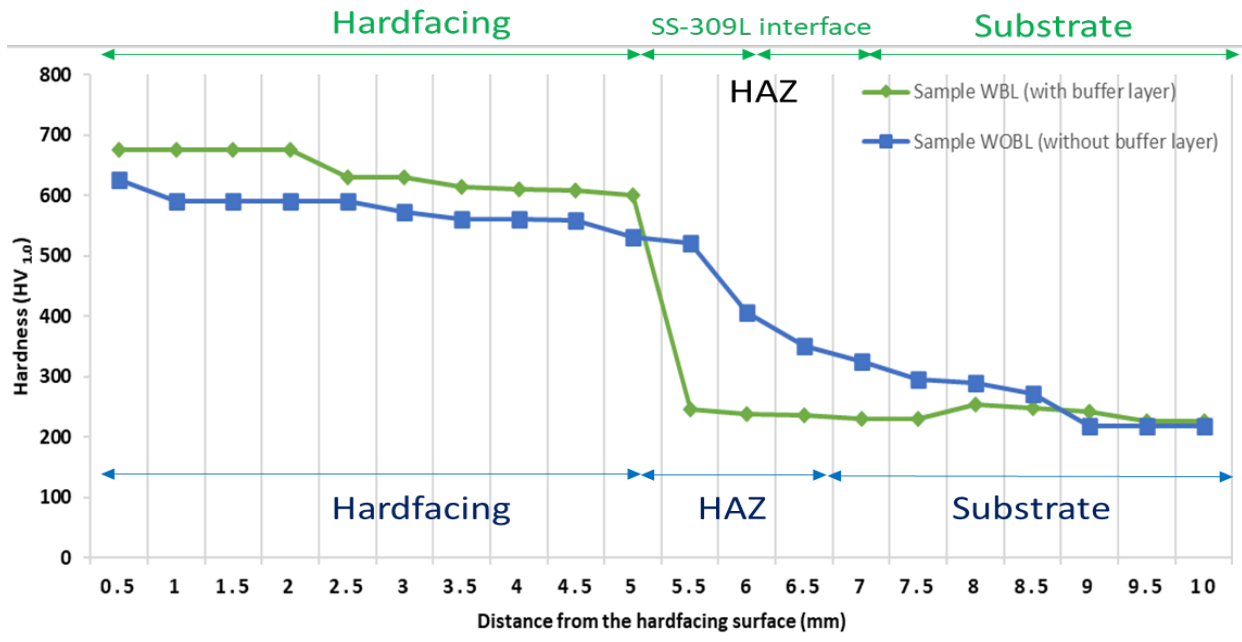

Figure 5. Microhardness results for both samples.

The aim of this research is to reduce HAZ hardness in order to avoid chances of delamination failure at the interface during service condition. From the investigations, hardness results show a significant decrement in HAZ region due to the introduction of austenitic material as SS-309L in between hardfacing and substrate. Buffer layer of SS-309L eventually avoids increase in the Fe content in the hardfacing layer from the substrate material which results in the constant higher hardness throughout the hardfacing layer thickness. Further, $\mathrm{Cr}$ content in SS-309L material causes increment in carbide formation in hardfacing layer which produces higher hardness in coating region. Hence, lower thickness of hardfacing layer can act as a sufficient deposition for service application which ensures reduced production cost. Apart from the lower production cost, this will further ensure lower chances of cracking tendency of weld hardfacing over P91 steels. Improved result observed for lower HAZ and higher coating hardness obtained with this material combination in comparison to previous research $[5,7]$.

\subsection{HAZ analysis}

In the literature, it is observed that delamination failure takes place below the fusion line where HAZ is formed during weld overlay application $[3,4]$. Hence, it is important to investigate HAZ region in terms of hardness, width and microstructural changes. During service applications, HAZ brittleness may be formed due to the presence of martensite together with stresses resulting from unmatched thermal expansion of substrate and coating material which can result in the formation of cracks. In this work, SS-309L material has been selected as buffer layer material between P91 and hardfacing material to create soft matrix. HAZ formed in P91 material for both approaches have been analyzed with the use of optical microscope. Figure 6 shows optical micrographs taken at interface and HAZ region for both samples.

Figure $6 a$ and $6 \mathrm{~b}$ represent the microstructural observations for HAZ region for sample WBL and WOBL. For P91 steels. Microstructural changes in HAZ region of P91 steel and HAZ width have been considered investigation aspects for this work. HAZ width has been significant factor affecting mechanical properties during high temperature applications [2]. It is suggested to minimize HAZ width for high temperature applications after hardfacing operations [1]. HAZ contains lath martensite microstructure that is characterized by its high hardness. In case of higher HAZ width, formation of lath martensite would act as hard substance together with hardfacing region. Hence, hard and brittle zone would be thicker which is unable to absorb generated residual thermal stresses and that can lead to cracking problem at the interface. Therefore, lower HAZ width acts as a one of the beneficial factors to avoid cracks near fusion lines for P91 steels [2,3]. For sample WBL, HAZ width is obtained around 1.6-1.8 mm and same is calculated from image analysis software attached with optical microscope. Whereas, for sample WOBL, HAZ width is obtained around 2.2-2.6 mm. HAZ width was measured and considered near P91 steel interface. Heat input for both processes is dissimilar due to different processing conditions. However, due to PWHT heat treatment after depositing FCAW buffer layer, less width of HAZ was observed in sample WBL. For sample WOBL, P91 steel was hardfaced directly by PTA which has resulted in higher HAZ width compared to sample WBL. These results have been confirmed with hardness indentations 
taken at these regions for both samples. Microstructural changes in HAZ are characterized with columnar laths tempered martensite structure with fine precipitates at the lath boundaries and within the matrix for both approaches. However, coarser grains in HAZ are characterized with columnar laths with tempered martensitic structure which cause higher HAZ hardness for the sample WOBL. In the sample WOBL, higher hardness of the coarser microstructure was observed due to a more complete precipitate dissolution during welding caused by longer times at high temperature during welding. This resulted from the higher heat input applied to the P91 substrate material in the sample WOBL. Finally, the dissolved elements in the HAZ would precipitate during PWHT resulting in higher hardness. Higher hardness due to coarse grains in HAZ was associated to the formation of martensite and the coarsening of precipitates [16]. On other hand, sample WBL exhibits tempered martensitic structure with finer grains in HAZ which justified the reason for obtained lower HAZ hardness in P91 steel [1]. Hence, hardness obtained for sample WBL (with buffer layer) is less than hardness obtained for sample WOBL (without buffer layer) approach. Therefore, it is suggested to deposit hardfacing layer with buffer layer of SS-309L material. This will ensure lower chances of cracking susceptibility during elevated temperature and pressure conditions in steam turbine applications. Due to double stage PWHT, brittleness and residual stresses are relieved from that zone and no microcracks are formed. The use of buffer layer between NiCrSiBC hardfacing and P91 steel substrate is strongly recommended because it gives lower HAZ hardness and HAZ.
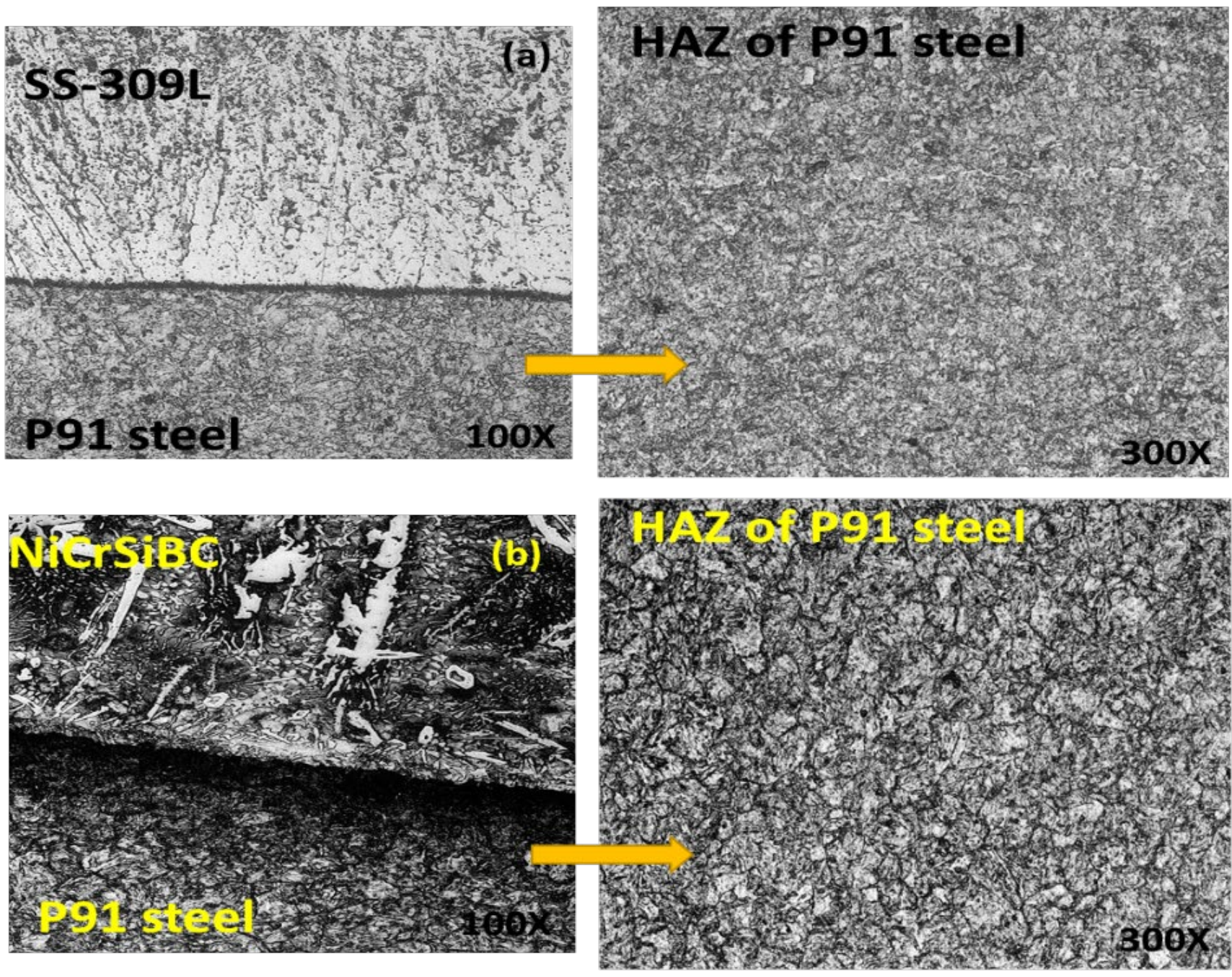

Figure 6. Optical micrographs of interface and HAZ (a) Sample WBL (b) Sample WOBL.

\subsection{Microstructural analysis}

Samples have been prepared and etched in accordance with ASTM E407 [15] for metallographic studies. Different microstructural zones of interest like hardfacing layer, interface and HAZ region for both approaches are observed with an optical microscope coupled with an image analysing software. Further, scanning electron microscope (SEM) is used to analyse microstructural changes present in sample WBL and sample WOBL. Figure 7 represents the microstructure obtained in hardfacing layer. 

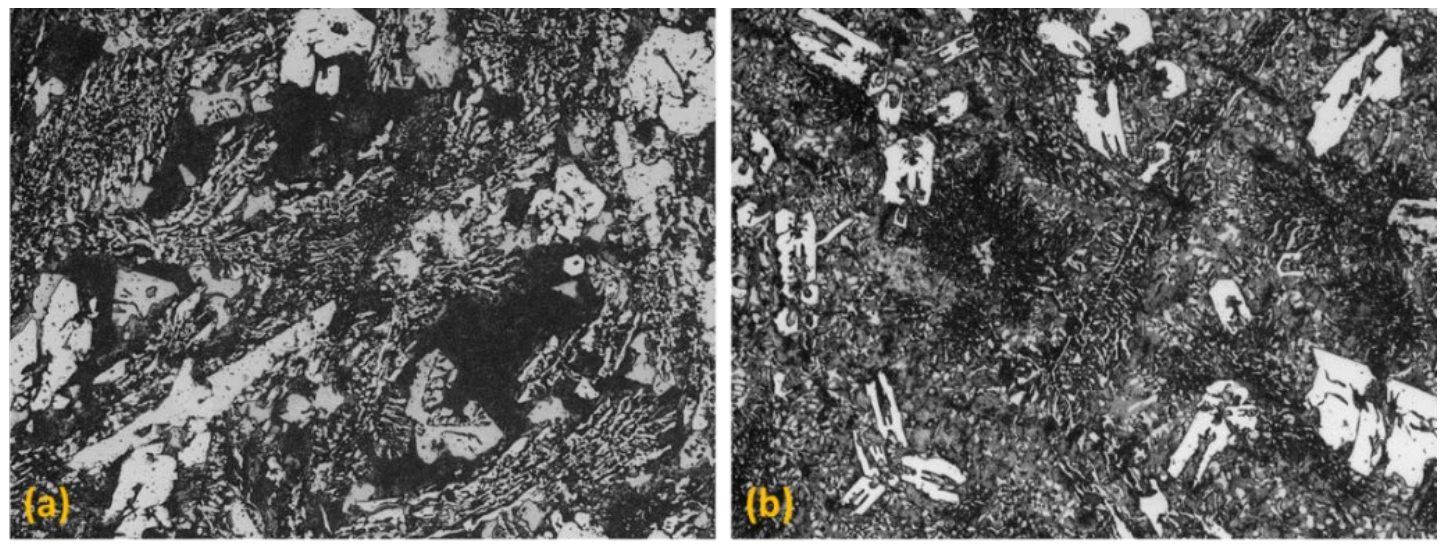

Figure 7. Optical micrographs of coating regions (a) Sample WBL (b) Sample WOBL.

Figure 7 represents the optical micrographs (magnification: 250X) taken in coating region which reflects uniformly distributed microstructure in both samples. Figure 7a depicts microstructure of with SS-309L buffer layer (sample WBL) approach and then hardfaced ( $\mathrm{NiCrSiBC}$ ) by PTA process. Fish bone structure, carbides and borides are observed in this micrograph. However, sample WOBL shows minor amount of carbides and borides along with higher amount of fish bone structure as shown in Figure 7b. This is the main observed difference in microstructure which results in a significant difference in hardness values obtained for both samples. Fish bone structure is observed in direct deposition of hardfacing material due to dilution of Fe and lower solidification rate. However, higher amount of $\mathrm{Cr}$ affects the formation of carbides and borides due to higher amount of $\mathrm{Cr}$ percentage in SS-309L material. SEM microstructural images of coating material and interface region are represented in different figures which are obtained from SEM at 300X magnification values. Figure 8a and 8b represent the microstructure obtained in coating regions for sample WBL and sample WOBL respectively.
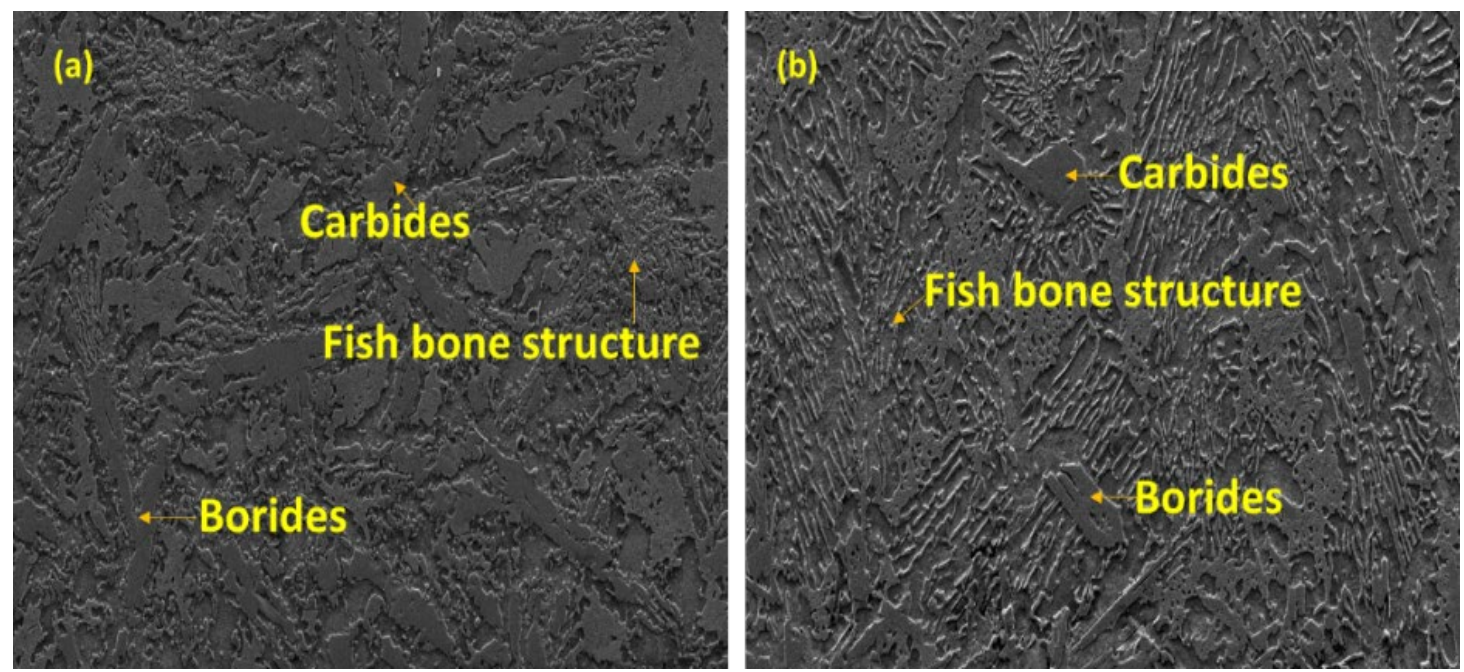

Figure 8. SEM micrographs (a) Sample WBL (b) Sample WOBL.

The microstructure of $\mathrm{NiCrSiBC}$ can be characterized by three different phases which includes hypereutectic matrix enriched with hard phases, lower amount of precipitate and dissolved spine like borides, carbides and some amount of hard particle grains uniformly distributed throughout the matrix. Preheat, interpass and PWHT conditions are said to be satisfactory due to the obtained results in terms of grain structure. Chemical composition of substrate material and dilution of Fe play a major role in the formation of these carbides and borides in hardfacing layer. $\mathrm{Cr}$ content is the major difference in chemical composition of SS-309L and P91 steels. However, solidification parameter (G*R, R- rate of solidification, G- temperature gradient) is another significant factor which influences the size of solidification structure and microstructural changes [17]. Solidification rate is affected by travel speed during weld deposition process [18]. In WBL sample the travel speed is $90 \mathrm{~mm} / \mathrm{min}$ whereas for WOBL sample it is $78 \mathrm{~mm} / \mathrm{min}$. Faster travel speed resulted in promoting the faster solidification rate compared to lower travel speed which shows slow solidification rate. Weld pool formed due to faster travel speed showed tear shaped weld pool in which the weld pool solidifies faster from the trailing edge [18]. Hence, slower solidification rate and lower preheating conditions in sample WOBL showed fish bone like structure. Faster solidification rate and higher preheating conditions in sample 
WBL promoted the uniform distribution and formation of carbides and borides throughout the microstructure. In WOBL sample, more time was available for solidification of weld pool due to its slower solidification rate which has resulted in microsegregation of solute redistribution in accordance with elements present in the hardfacing surface. Therefore, it has resulted in fish bone structure in sample WOBL in large amount than the sample WBL.
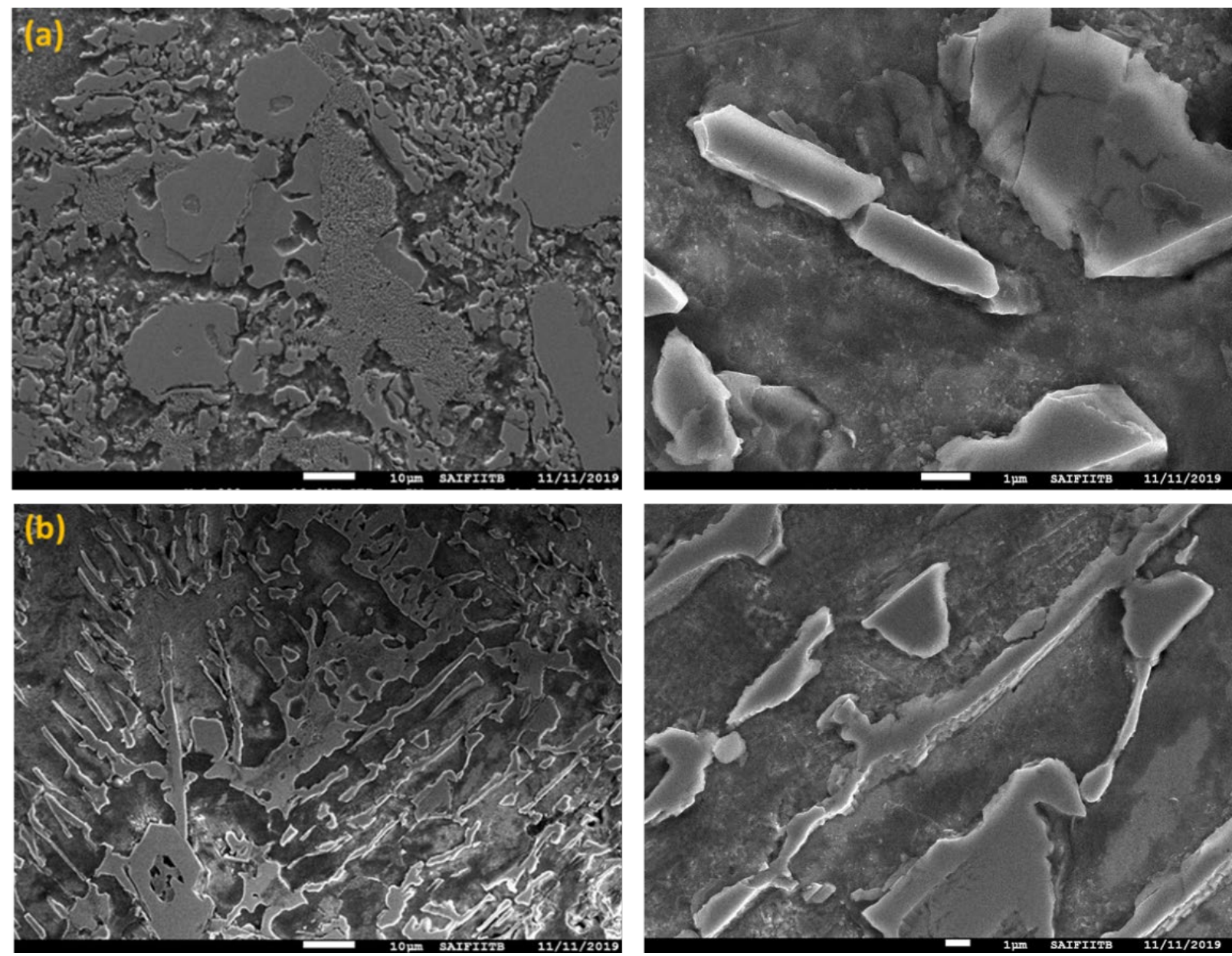

Figure 9. SEM micrographs of coating region (a) Sample WBL (b) Sample WOBL.

Figure 9 (a) and 9 (b) depict micrographs at higher magnification for sample WBL (with buffer layer) and sample WOBL (without buffer layer) respectively to investigate microconstituent formation. In sample WOBL (without buffer layer), preheating conditions are different than the sample of WBL (with buffer layer) to varied substrate material during hardfacing operation. This causes alteration in the solidification rate of both the samples. When temperature gradient decreases, solidification rate increases along with the higher segregation at solidification front [18]. This ratio $(G * R)$ changes rapidly with the start of cooling cycle which remains constant in the final stages of solidification [17]. Overall, fish bone like dendritic growth and coarser microstructure was observed in sample WOBL and that has resulted in lower coating hardness than sample WBL. Higher hardness in sample WBL has been observed with finer microstructure and uniformly distributed hard phases due to higher solidification rate and higher preheating conditions. However, differences are also observed in the formation of the borides $\mathrm{Cr}_{5} \mathrm{~B}_{3}$ (block shaped patches) in the sample WBL and $\mathrm{CrB}$ (needle shaped in fish bone structure) in the sample of WOBL. This is due to the explanation given on the basis of peritectic reaction $\left(\mathrm{L}+\mathrm{CrB} \rightarrow \mathrm{Cr}_{5} \mathrm{~B}_{3}\right)$ that befalls around $1899^{\circ} \mathrm{C}$ in the binary phase illustration of $\mathrm{Cr}-\mathrm{B}$ [12]. The development of the $\mathrm{Cr}_{5} \mathrm{~B}_{3}$ boride can be controlled by the elemental ( $\mathrm{B}$ and $\mathrm{Cr}$ ) diffusion. For sample WBL, higher preheat and interpass conditions as well as higher percentage of $\mathrm{Cr}$ may be considered as a significant factor affecting the growth of boride $\left(\mathrm{Cr}_{5} \mathrm{~B}_{3}\right)$ formation along with cube shaped carbide $\left(\mathrm{Cr}_{7} \mathrm{C}_{3}\right)$ formation [12]. This phase formation can be studied by X-ray diffraction (XRD) analysis and energy dispersive spectroscopy (EDS) analysis. Elemental composition (Cr) and application of buffer layer influence the microstructural changes which results in the variation of hardness in hardfacing layers of both the samples. The formation of hard phases like $\mathrm{Cr}$ borides and $\mathrm{Cr}$ carbides induce the hardness in hardfacing layer. However, volume fraction analysis by XRD and EDS has confirmed the reasons for an increased hardness in the sample of WBL as compared to the sample of WOBL due to varying volume fraction of carbides and borides. 


\subsection{Elemental analysis}

EDS line scan analysis and point analysis were carried out with low acceleration electron ( $5 \mathrm{kV}$ ) for both the approaches. EDS analysis has been conducted for the sample of WBL and for the sample of WOBL in the hardfacing region which is represented in Figure 10a and 10b respectively. Dilution of Fe is considered for this study as Fe content acts as the most significant factor affecting hardness value $[2,8]$. EDS spot for Fe content is measured just above the fusion line which is the matter of interest for evaluating mechanical properties. EDS spot measurements were taken at 4 different spots and there was less than $1 \%$ difference observed amongst 4 different spots for Fe content. Hence, average values have been considered for Fe content measurement and from Equation 1, dilution of Fe has been calculated. From the results, $6.73 \%$ and $14.06 \%$ were the calculated values of Fe for sample WBL (with buffer layer) and sample WOBL (without buffer layer) respectively. Lower dilution of Fe content can result in higher hardness as was observed in sample WBL. Since, less dilution of Fe favours higher hardness for hardfacing operations $[2,8]$.

\section{EDS spot}
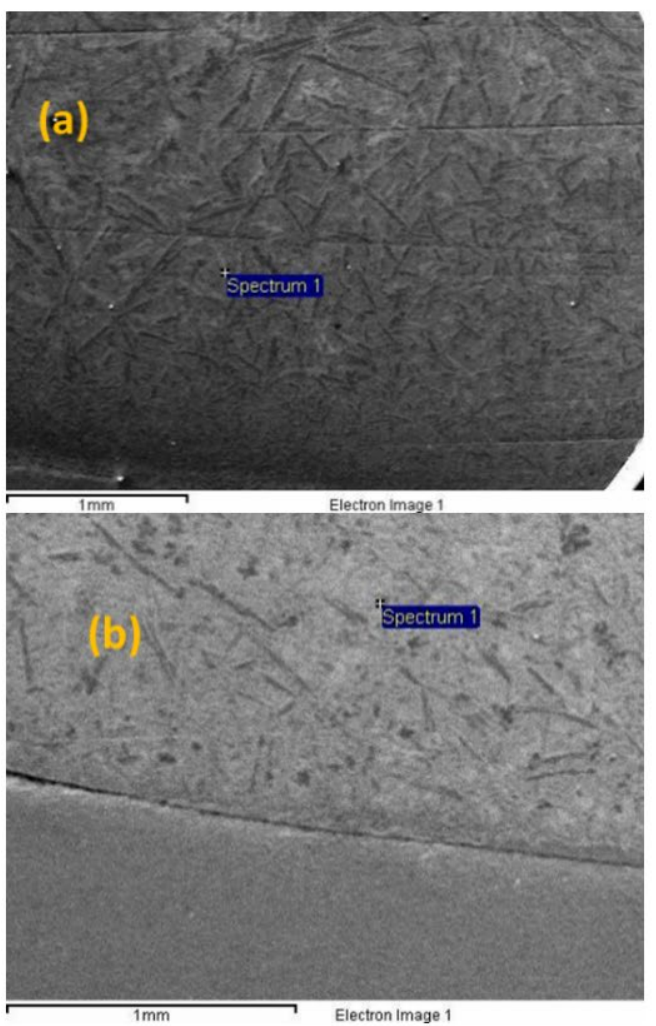

\section{Elemental distribution}
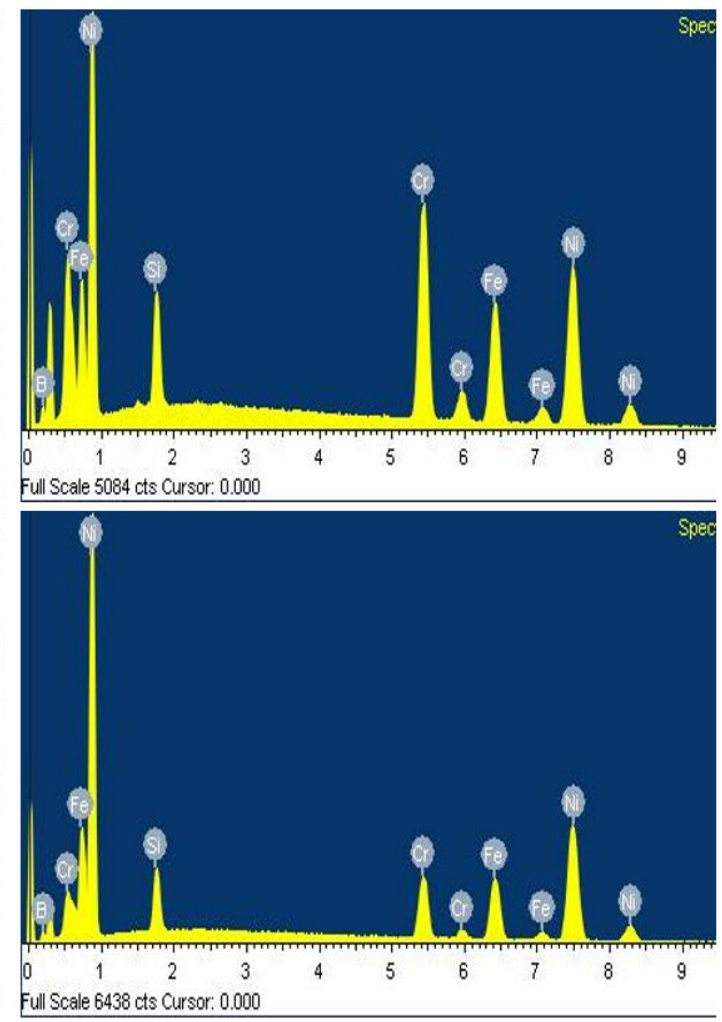

$\begin{array}{cc}\begin{array}{c}\text { Element } \\ \text { name } \\ \mathrm{Fe}\end{array} & \begin{array}{c}\text { Wt. } \\ \mathbf{( \% )}\end{array} \\ 9.25 \\ \mathrm{Cr} & 19.75 \\ \mathrm{Ni} & 49.50 \\ \mathrm{~B} & 18.53 \\ \mathrm{Si} & 2.97 \\ \begin{array}{c}\text { Element } \\ \text { name }\end{array} & \begin{array}{c}\mathbf{W t} . \\ \mathbf{( \% )}\end{array} \\ \mathrm{Fe} & 15.82 \\ \mathrm{Cr} & 10.42 \\ \mathrm{Ni} & 55.75 \\ \mathrm{~B} & 14.92 \\ \mathrm{Si} & 3.09\end{array}$

Figure 10. EDS spot analysis (a) Sample WBL (b) Sample WOBL.

Further, $\mathrm{Cr}$ percentage has increased values in sample WBL (with buffer layer) compared to sample WOBL (without buffer layer). This ensures the increased hardness value of hardfacing layer for sample WBL. Buffer layer of higher $\mathrm{Cr}$ percentage forms the higher volume fraction of carbides and borides in block shapes forming higher hardness. Further, EDS line scan is used to study the elemental distribution across the fusion line which is presented in Figure $11 \mathrm{a}$ and $11 \mathrm{~b}$. EDS line scan has been conducted from coating region to substrate region which consists of HAZ too. For both the samples, three elements (Fe, Ni and $\mathrm{Cr}$ ) have been considered in this study as these elements are significant factors for the formation of phases and the growth of dendritic structure. Major elemental changes are observed between two elements (Fe and $\mathrm{Cr}$ ) which are considered as significant elements affecting mechanical properties and phase formation.

Figure 11 shows EDS line scan, in which similar distributions of $\mathrm{Fe}, \mathrm{Cr}$ and $\mathrm{Ni}$ are observed in both samples. This is the major reason for homogeneity of microstructure across the regions of hardfacing layer. Major difference is observed in $\mathrm{Cr}$ content in hardfacing layer which is the reason for higher hardness obtained in sample WBL. Cr has segregated effectively from buffer layer since SS-309L has $18-20 \% \mathrm{Cr}$ when it is compared to $9 \mathrm{Cr}-1 \mathrm{Mo}$ steel $(8-9 \% \mathrm{Cr}$ ). Further, boron content has played role in the formation of $\mathrm{Cr}_{7} \mathrm{C}_{3}$ and $\mathrm{CrB}$ [17-19] with sufficient provision of $\mathrm{Cr}$ from buffer layer (SS-309L). This has increased hardness of sample WBL (with buffer layer) which is beneficial for bushes and valve disc component in considered service applications. 

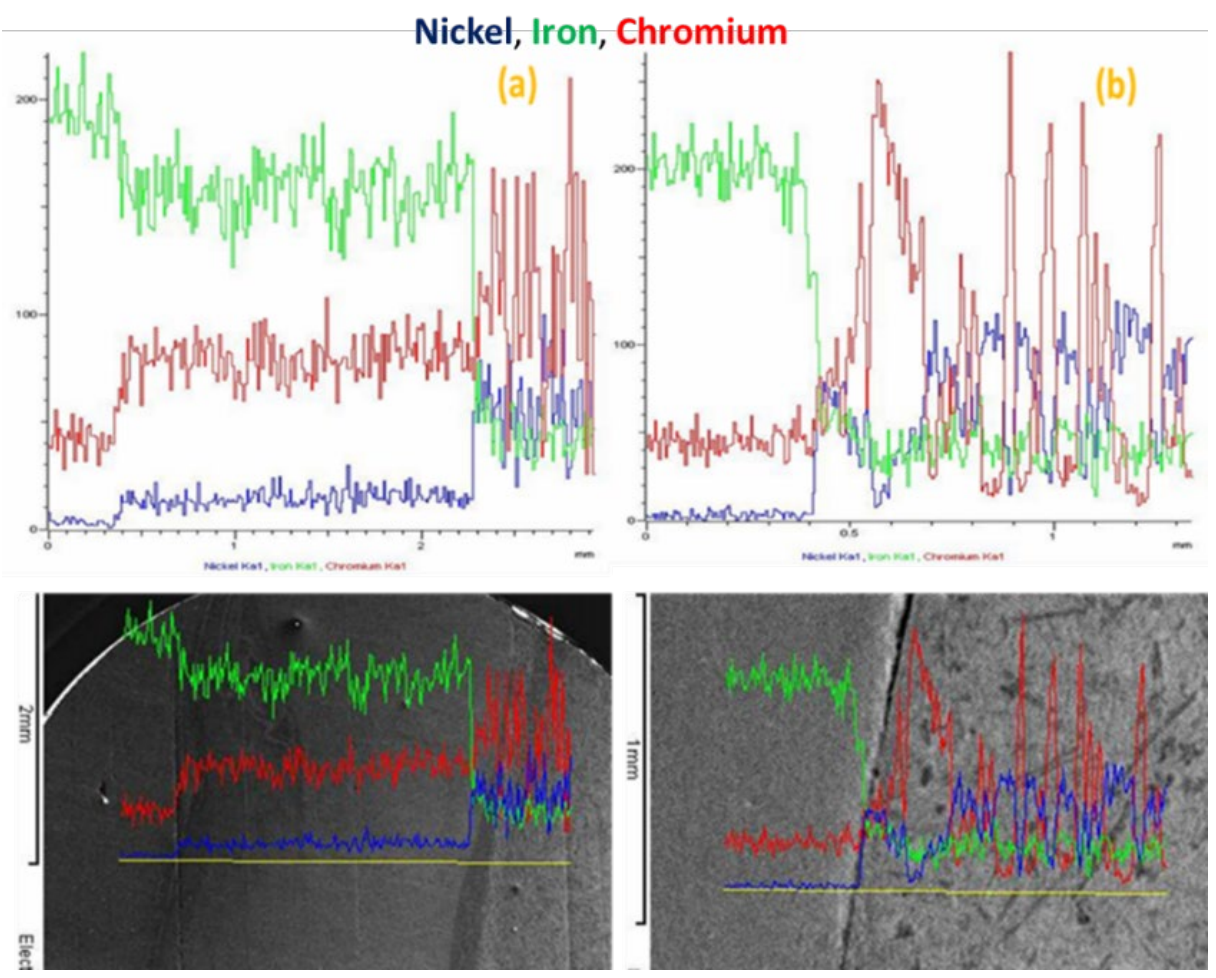

Figure 11. EDS line scan analysis (a) Sample WBL (b) Sample WOBL.

EDS spot
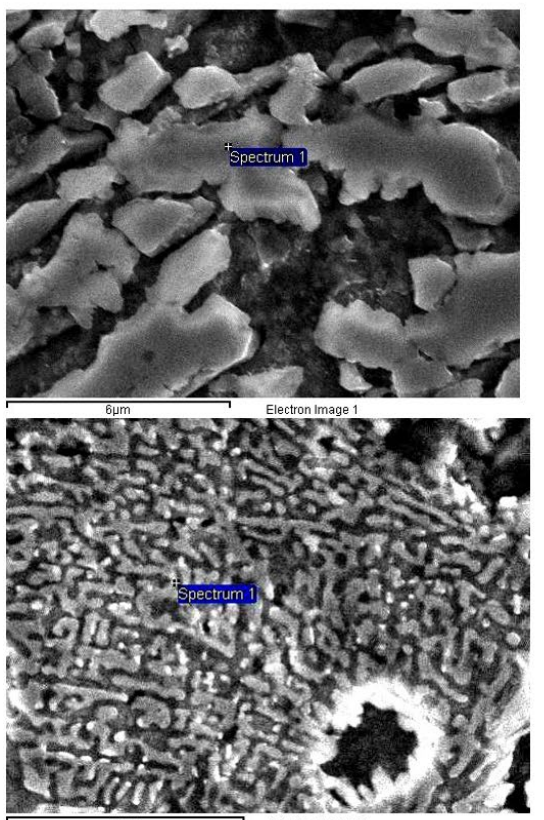

Elemental distribution
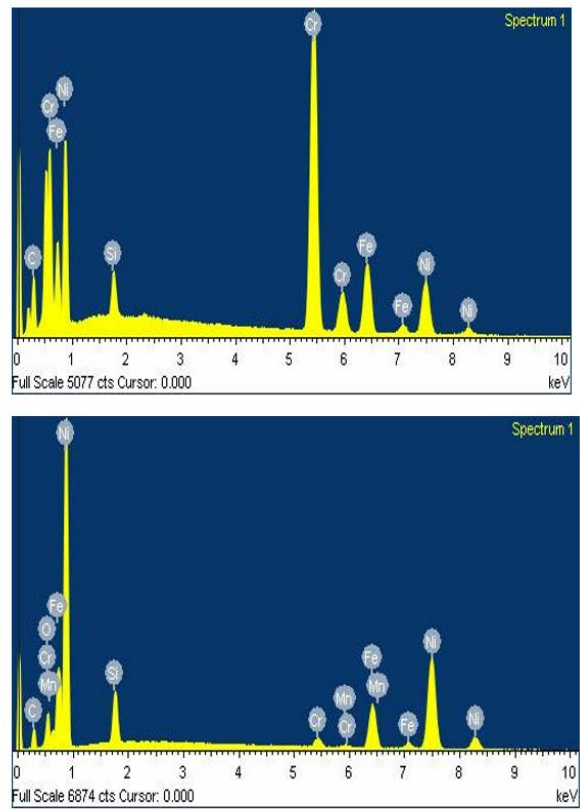

Figure 12. EDS spot phase analysis for sample WBL.

Figure 12 represents the EDS spot analysis performed in sample WBL at major microstructural constituents in the form of cubes and needles. This has confirmed the presence of $\mathrm{Cr}(48.26 \%)$ and $\mathrm{C}(10.21 \%)$ majorly hence, formation of $\mathrm{Cr}$ carbides and borides has been ensured. However, nickel solid solution was observed with higher content of nickel (64.91\%) and less content of $\mathrm{Cr}(2.25 \%)$ in second spot. These results have been further compared and analyzed with XRD phase analysis. Figure 13 represents the EDS spot analysis taken at major microstructural constituents in the form of fish bone like structure along with few cube shaped carbides observed in sample WOBL (without buffer layer). 
EDS spot
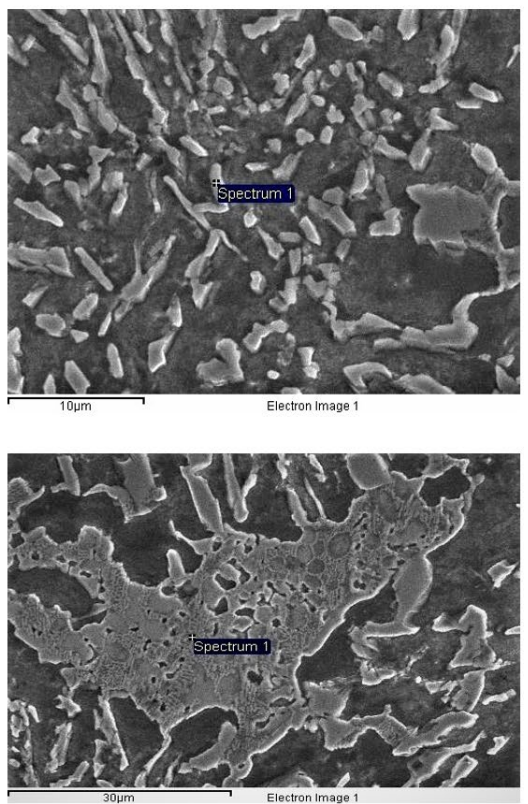

Elemental distribution

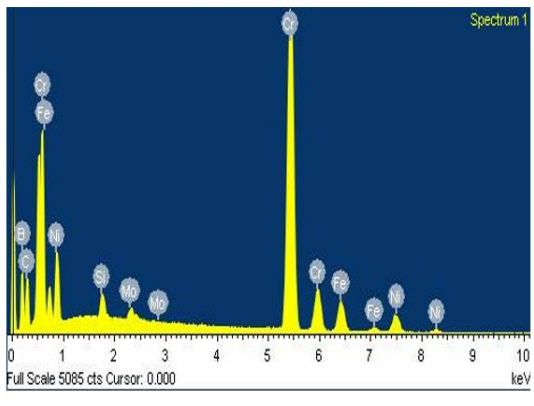

$\begin{array}{cc}\begin{array}{c}\text { Element } \\ \text { name }\end{array} & \begin{array}{c}\text { Wt. } \\ (\%)\end{array} \\ \mathrm{B} & 21.00 \\ \mathrm{C} & 15.06 \\ \mathrm{Cr} & 47.62 \\ \mathrm{Fe} & 7.20 \\ \mathrm{Ni} & 7.71\end{array}$

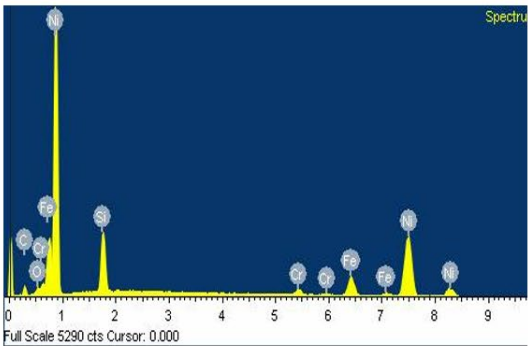

$\begin{array}{cc}\begin{array}{c}\text { Element } \\ \text { name }\end{array} & \begin{array}{c}\text { Wt. } \\ (\%)\end{array} \\ \mathrm{C} & 6.89 \\ \mathrm{Si} & 7.90 \\ \mathrm{Cr} & 2.05 \\ \mathrm{Fe} & 10.93 \\ \mathrm{Ni} & 71.4\end{array}$

Figure 13. EDS spot phase analysis for sample WOBL.

The results obtained in Figure 12 and Figure 13 are same for cube/needle like constituents which are same and it is the solid solution of nickel matrix. This has been proved by EDS spot analysis on the given morphology for both samples. On other hand, Figure 13 represents the boride formation $\left(\mathrm{CrB}, \mathrm{CrB}_{4}, \mathrm{Cr}_{2} \mathrm{~B}\right.$ and $\left.\mathrm{Cr}_{5} \mathrm{~B}_{3}\right)$ sample WOBL for the reference. Similar phase was also observed in higher intensity in sample WBL which has confirmed by XRD analysis. Figure 12 and Figure 13 are sample representations of EDS spot analysis which was used to determine phases and microstructural changes present in both samples.

\subsection{XRD phase analysis}

Phase analysis on the top region of hardfacing (polished and machined) are investigated with XRD technique. A better justification of the observed coating hardness for both the approaches has been obtained by XRD analysis as depicted in Figure 14. Formation of certain phases is the main reason for the difference observed in coating hardness which explains strong dependence on the chemical composition of substrate material. From SEM analysis, formation of chromium borides is main difference between the sample of WBL and the sample of WOBL approach. Further, more analysis of these alloys using different techniques like SEM, transmission election microscopy, etc. are outside the research scope of this work but the same can be available in literature $[12,14,19-21]$.

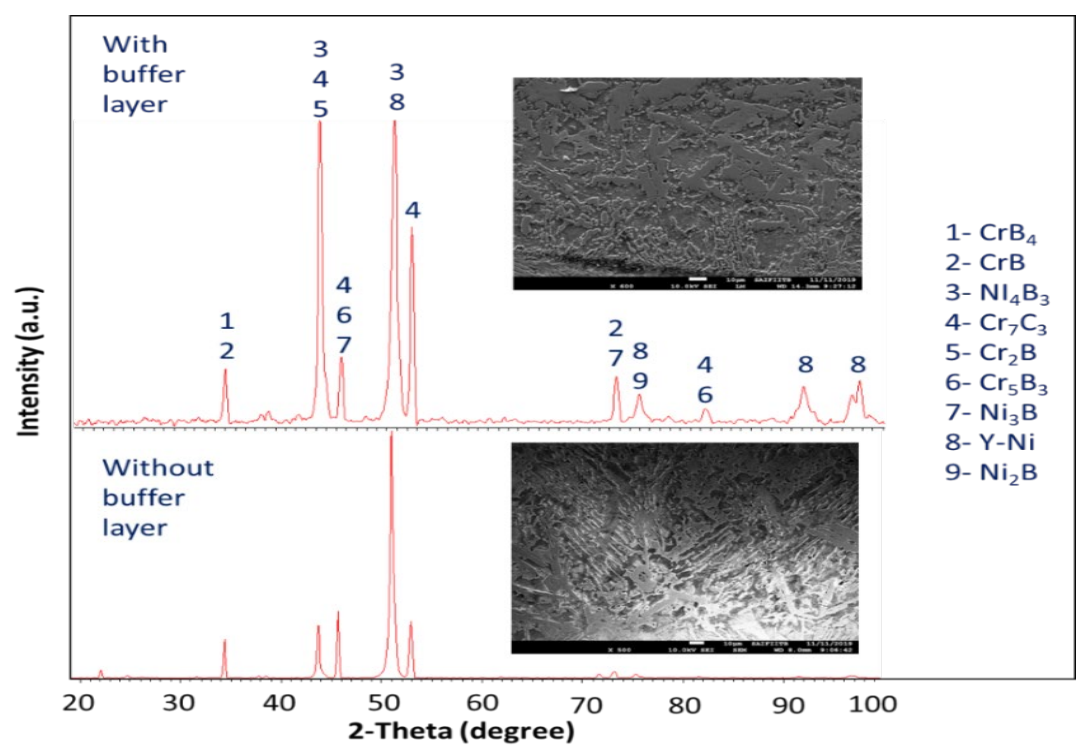

Figure 14. XRD results for sample WBL and sample WOBL. 
Numerous phases are identified which confirms the complexity of the materials and significant influence of elemental composition of the substrate material. $\mathrm{CrB}_{4}, \mathrm{CrB}, \mathrm{Ni}_{4} \mathrm{~B}_{3}, \mathrm{Cr}_{7} \mathrm{C}_{3}, \mathrm{Cr}_{2} \mathrm{~B}$ and $\mathrm{Cr}_{5} \mathrm{~B}_{3}$ are identical phases present in both approaches. However, $\mathrm{Cr}_{7} \mathrm{C}_{3}$. $\mathrm{Cr}_{2} \mathrm{~B}$ and $\mathrm{Cr}_{5} \mathrm{~B}_{3}$ are phases observed with low symmetry in the case of sample WOBL. There are few low peaks observed in large quantities which are difficult to analysis due to pronounced texture, increased solubility and high residual stresses observed in sample WOBL. However, by using Rietveld optimization and refinement method, phases may be resolved [12,21-22]. High volume fraction of carbides and borides are identified by EDS and XRD in sample WBL (with buffer layer). The main reason behind this formation is chemical composition of substrate material which was SS-309L in the case of indirect deposition (with buffer layer) approach. Higher percentage of $\mathrm{Cr}$ infuses with $\mathrm{NiCrSiBC}$ hardfacing develops blocky formation of carbides and borides which in turns help to improvise coating hardness. However, due to less $\mathrm{Cr}$ percentage and lower solidification rate have forms needle shaped borides in sample WOBL (without buffer layer) approach. The fish bone and dendritic structure observed in sample WOBL with clear absence of dispersed borides and carbides justifies the significant influence of substrate chemical composition on coating hardness [13]. Hence, with application of buffer layer, coating hardness is improvised due to favorable chemical composition of substrate material. These hard particles and phases are formed in $\gamma$-nickel matrix solid solution. Hence, few peaks are observed in accordance with $\gamma$ - nickel matrix solid solution. Processing conditions like solidification rate, current and chemical composition of hardfacing material have impact on the formation of the said solid solution.

\subsection{Comparative analysis for both weld hardfacing approaches}

On the basis of experimental and metallurgical investigations for both samples individually, Table 3 represents the important comparative analysis from this research work.

Table 3. Comparative analysis for both weld hardfacing approaches.

\begin{tabular}{|c|c|c|c|c|}
\hline Sr. No. & Criteria for comparison & $\begin{array}{l}\text { Results obtained for sample WBL } \\
\text { approach }\end{array}$ & $\begin{array}{l}\text { Results obtained for } \\
\text { sample WOBL approach }\end{array}$ & $\begin{array}{l}\text { Conclusive } \\
\text { statement }\end{array}$ \\
\hline 1. & Microhardness study & $\begin{array}{c}\S \mathrm{HAZ} \text { hardness is around } 250 \mathrm{HV} \\
\S \text { Coating hardness is around } 630 \\
\text { HV }\end{array}$ & $\begin{array}{c}\S \mathrm{HAZ} \text { hardness is around } \\
420 \mathrm{HV} \\
\S \text { Coating hardness is } 550 \\
\text { HV }\end{array}$ & $\begin{array}{l}\text { Sample WBL } \\
\text { approach is more } \\
\text { suitable. }\end{array}$ \\
\hline 2. & HAZ width & $\S 1.6-1.8 \mathrm{~mm}$ & $\S 2.2-2.6 \mathrm{~mm}$ & $\begin{array}{l}\text { Sample WBL } \\
\text { approach is more } \\
\text { suitable. }\end{array}$ \\
\hline \multirow{3}{*}{3.} & \multirow{3}{*}{$\begin{array}{l}\text { Microstructural examination } \\
\text { by optical microscope }\end{array}$} & $\begin{array}{l}\S \text { Uniform microstructure with no } \\
\text { cracks or voids }\end{array}$ & $\begin{array}{l}\S \text { Uniform microstructure } \\
\text { with no cracks or voids }\end{array}$ & \multirow{3}{*}{$\begin{array}{c}\text { Sample WBL } \\
\text { approach is more } \\
\text { suitable. }\end{array}$} \\
\hline & & $\begin{array}{c}\S \text { Star shaped cubes, blocky and } \\
\text { needle shaped carbides and } \\
\text { borides were observed }\end{array}$ & $\begin{array}{c}\S \text { Fish bone structure, } \\
\text { carbides and borides in } \\
\text { long needle shape were } \\
\text { observed }\end{array}$ & \\
\hline & & $\begin{array}{c}\S \text { Lower amount of fish bone } \\
\text { structure observed }\end{array}$ & $\begin{array}{c}\S \text { Fine elongated grains } \\
\text { are precipitated from } \mathrm{Cr} \\
\text { element as nucleation } \\
\text { site }\end{array}$ & \\
\hline \multirow[t]{2}{*}{4.} & \multirow{2}{*}{$\begin{array}{c}\text { Microstructural examination } \\
\text { by SEM }\end{array}$} & $\begin{array}{l}\S \text { Block shaped and needle like } \\
\text { structure are observed }\end{array}$ & $\begin{array}{l}\S \text { Fish bone structure } \\
\text { along with block shaped } \\
\text { structure are observed }\end{array}$ & \multirow{2}{*}{$\begin{array}{l}\text { Sample WBL } \\
\text { approach is more } \\
\text { suitable. }\end{array}$} \\
\hline & & $\begin{array}{c}\S \mathrm{Cr}_{5} \mathrm{~B}_{3} \text { and Carbides phase are } \\
\text { observed in blocky shape }\end{array}$ & $\begin{array}{c}\S \mathrm{CrB} \text { and carbides are } \\
\text { observed in needle shape }\end{array}$ & \\
\hline 5. & Dilution of Fe element by EDS & $\S 9.25 \%$ of Fe in the coating region & $\begin{array}{c}\S 15.82 \% \text { of } \mathrm{Fe} \text { in the } \\
\text { coating region }\end{array}$ & $\begin{array}{c}\text { Sample WBL } \\
\text { approach is more } \\
\text { suitable. }\end{array}$ \\
\hline \multirow[t]{2}{*}{6.} & \multirow[t]{2}{*}{ Phase morphology by XRD } & $\begin{array}{c}\S \mathrm{Cr}_{7} \mathrm{C}_{3} \cdot \mathrm{Cr}_{2} \mathrm{~B} \text { and } \mathrm{Cr}_{5} \mathrm{~B}_{3} \text { are phases } \\
\text { in higher fraction }\end{array}$ & $\begin{array}{c}\S \mathrm{Cr}_{7} \mathrm{C}_{3} \cdot \mathrm{Cr}_{2} \mathrm{~B} \text { and } \mathrm{Cr}_{5} \mathrm{~B}_{3} \\
\text { are phases in lower } \\
\text { fraction }\end{array}$ & \multirow{2}{*}{$\begin{array}{l}\text { Sample WBL } \\
\text { approach is more } \\
\text { suitable. }\end{array}$} \\
\hline & & $\begin{array}{c}\S \curlyvee \text { - nickel matrix solid solution } \\
\text { observed }\end{array}$ & $\begin{array}{l}\S \curlyvee \text { - nickel matrix solid } \\
\text { solution observed }\end{array}$ & \\
\hline 7. & Coating thickness & $\S 5.376 \mathrm{~mm}$ & $\S 5.509 \mathrm{~mm}$ & $\begin{array}{c}\text { Both approaches can } \\
\text { be used. }\end{array}$ \\
\hline
\end{tabular}




\section{Conclusions}

Overall, this research work aims to develop and to select an effective weld hardfacing approach which exhibits higher coating hardness, lower HAZ hardness and desired microstructural characteristics with reduced chances of cracks during service life. Major concluding remarks are as follows:

- From the investigations, higher coating hardness (630 HV), lower HAZ hardness (250 HV), lower HAZ width (1.6-1.8 mm) and lower Fe dilution (9.25\% of Fe) are observed in sample WBL (with buffer layer). $\mathrm{Cr}_{7} \mathrm{C}_{3} . \mathrm{Cr}_{2} \mathrm{~B}$ and $\mathrm{Cr}_{5} \mathrm{~B}_{3}$ are hard phases observed in blocky shape along with $\curlyvee$ - nickel matrix solid solution for sample WBL.

- With increment of temperature gradient, solidification rate decreases causing the segregation at solidification front resulting in fish bone dendritic growth with carbides and borides in long needle shape during sample WOBL (without buffer layer). Hence, sample WBL (indirect deposition with SS-309L buffer layer and NiCrSiBC as hardfacing material) is an appropriate solution to reduce delamination failure and to improve coating hardness.

The hardfacing technique for weld deposition of NiCrSiBC involving buffer layer of SS-309L has been demonstrated to be technically suitable for hardfacing of valve seat and bush as well as component made of P91 steel. Further, it is planned to investigate high temperature wear behavior of established approach of NiCrSiBC hardfacing for P91 steels.

\section{Acknowledgement}

Authors are thankful to M/S L\&T MHPS Turbine Generators Pvt. Ltd., Hazira, Gujarat, India, for providing high quality machines, materials and testing facilities to accomplish the essential experimental investigations.

\section{References}

[1] Pandey C, Giri A, Mahapatra MM, Kumar P. Characterization of microstructure of HAZs in as-welded and service condition of P91 pipe weldments. Metals and Materials International. 2017;23(1):148-162. http://dx.doi.org/10.1007/s12540-017-6394-5.

[2] Kumar H, Albert SK, Sudha C, Vijayashree R, Bhaduri AK, Balasubramanian C. Hardfacing of a modified $9 \mathrm{Cr}-1 \mathrm{Mo}$ steel component using a nickel-base alloy. Transactions of the Indian Institute of Metals. 2011;64(4-5):339-343. http://dx.doi.org/10.1007/s12666-011-0087-4.

[3] Ferozhkhan MM, Kumar KG, Ravibharath R. Metallurgical study of Stellite 6 cladding on 309-16L stainless steel. Arabian Journal for Science and Engineering. 2017;42(5):2067-2074. http://dx.doi.org/10.1007/s13369-017-2457-7.

[4] Lolla T, Siefert J, Babu SS, Gandy D. Delamination failures of Stellite hardfacing in power plants: a microstructural characterisation study. Science and Technology of Welding and Joining. 2014;19(6):476-486. http://dx.doi.org/10.1179/1362171814Y.0000000213.

[5] Antoszczyszyn TJ, Paes RM, Oliveira AS, Scheid A. Impact of dilution on the microstructure and properties of Ni-based 625 alloy coatings. Soldagem e Inspeção. 2014;19(2):134-144. http://dx.doi.org/10.1590/0104-9224/SI1902.05.

[6] Bhaduri AK, Albert SK, Das CR, Raj B. Hardfacing of austenitic stainless steel with nickel-base NiCr alloy. International Journal of Microstructure and Materials Properties. 2011;6(1-2):40-53. http://dx.doi.org/10.1504/IJMMP.2011.040436.

[7] Chakraborty G, Das CR, Albert SK, Bhaduri AK, Murugesan S, Dasgupta A. Effect of alloy 625 buffer layer on hardfacing of modified 9Cr1 Mo steel using nickel base hardfacing alloy. Journal of Materials Engineering and Performance. 2016;25(4):1663-1672. http://dx.doi.org/10.1007/s11665-016-1965-z.

[8] Deshmukh DD, Kalyankar VD. Recent status of overlay by plasma transferred arc welding technique. International Journal of Materials \& Product Technology. 2018;56(1-2):23-83. http://dx.doi.org/10.1504/IJMPT.2018.089118.

[9] Zhou YX, Zhang J, Xing ZG, Wang HD, Lv ZL. Microstructure and properties of NiCrBSi coating by plasma cladding on gray cast iron. Surface and Coatings Technology. 2019;361:270-279. http://dx.doi.org/10.1016/j.surfcoat.2018.12.055.

[10] da Silva L, Scheuer CJ, D’Oliveira AS. Effect of microstructure on wear performance of NiCrSiBC coatings. Wear. 2019;428:387-394. http://dx.doi.org/10.1016/j.wear.2019.04.005.

[11] Kesavan D, Kamaraj M. The microstructure and high temperature wear performance of a nickel base hardfaced coating. Surface and Coatings Technology. 2010;204(24):4034-4043. http://dx.doi.org/10.1016/j.surfcoat.2010.05.022.

[12] Hemmati I, Huizenga RM, Ocelík V, De Hosson JT. Microstructural design of hardfacing Ni-Cr-B-Si-C alloys. Acta Materialia. 2013;61(16):6061-6070. http://dx.doi.org/10.1016/j.actamat.2013.06.048.

[13] Reinaldo PR, D'Oliveira AS. NiCrSiB coatings deposited by plasma transferred arc on different steel substrates. Journal of Materials Engineering and Performance. 2013;22(2):590-597. http://dx.doi.org/10.1007/s11665-012-0271-7.

[14] American Society of Mechanical Engineers. ASME Section IX. Qualification Standard for Welding and Brazing Procedures, Welders, Brazers and Welding and Brazing Operators. New York: ASME; 2017.

[15] American Society for Testing and Materials. ASTM E407-15: Standard Practice for Microetching Metals and Alloys. New York: ASME; 2015. 
[16] Gutierrez NZ, Alvarado JV, de Cicco H, Danon A. Microstructural study of welded joints in a high temperature martensitic-ferritic ASTM A335 P91 steel. Procedia Materials Science. 2015;8(1):1140-1149. http://dx.doi.org/10.1016/j.mspro.2015.04.178.

[17] da Silva L, D'Oliveira AS. NiCrSiBC alloy: microstructure and hardness of coatings processed by arc and laser. Welding International. 2017;31(1):1-8. http://dx.doi.org/10.1080/09507116.2016.1218608.

[18] Kou S. Welding metallurgy. New Jersey: John Wiley \& Sons, Inc.; 2003. p. 431-446.

[19] Hemmati I, Ocelík V, Csach K, De Hosson JT. Microstructure and phase formation in a rapidly solidified laser-deposited Ni-Cr-B-Si-C hardfacing alloy. Metallurgical and Materials Transactions. A, Physical Metallurgy and Materials Science. 2014;45(2):878-892. http://dx.doi.org/10.1007/s11661-013-2004-4.

[20] Hemmati I, Rao JC, Ocelík V, De Hosson JT. Electron microscopy characterization of Ni-Cr-B-Si-C laser deposited coatings. Microscopy and Microanalysis. 2013;19(1):120-131. http://dx.doi.org/10.1017/S1431927612013839. PMid:23347419.

[21] Rojacz H, Zikin A, Mozelt C, Winkelmann H, Badisch E. High temperature corrosion studies of cermet particle reinforced NiCrBSi hardfacings. Surface and Coatings Technology. 2013;222:90-96. http://dx.doi.org/10.1016/j.surfcoat.2013.02.009.

[22] Cardozo EP, Pardal GR, Ríos S, Ganguly S, D’Oliveira AS. Additive techniques to refurbish Ni based components. Soldagem e Inspeção. 2019;24:e2403. http://dx.doi.org/10.1590/0104-9224/si24.03. 